\title{
The Recruitment of Female "Mules" by Transnational Criminal Organizations Securitization of Drug Trafficking in the Philippines and Beyond ${ }^{1}$
}

Southeast Asia has long been vulnerable to drug trafficking. Recently, intensified flows of persons, goods, and capital across borders have rendered it more fragmented and complex. The recruitment of female drug "mules" by transnational criminal organizations is a growing concern for both national and international counter-trafficking authorities in the region. This phenomenon has been the focus of a particular securitization process, emerging primarily in the Philippines but having regional implications, which has supported the implementation of counter-trafficking policy initiatives on both levels of state and region in Southeast Asia. 


\section{INTRODUCTION}

Southeast Asia has long been vulnerable to drug trafficking. Nowadays, transnational criminal organizations (TCOs) operating in the region are a growing concern for national authorities as well as international organizations. Intensified flows of persons, goods, and capital across borders, both licit and illicit, have rendered drug trafficking more fragmented and complex, and thus harder to counter. Since the sudden surge of trafficking in amphetamine-type stimulants in Southeast Asia during the 1990s, modes of operation characterizing the regional drug trade have considerably changed. One of the emerging patterns is the increasing use of women as drug "mules," defined as "those who carry drugs bought by someone else across national borders" (Fleetwood and Haas 2011, 197). This phenomenon has been the focus of a particular securitization process, emerging primarily in the Philippines, which has been a major hub for crystal methamphetamine trafficking since the middle of the 1990s. Official statements focusing on the victimization of Filipino nationals, especially women, by TCOs have supported the implementation of counter-trafficking policy initiatives. This focus is part of a wider securitization process that is taking place in Southeast Asia at both levels of state and region, having implications for multilateralism in the field of security.

\section{SECURITIZATION AS A CONTINUUM: INSIGHTS FROM SOUTHEAST ASIA}

It has been generally acknowledged that since the end of the Cold War, the scope of security has broadened and deepened, and the range of phenomena considered has consequently been expanded to include a wider host of issues (Jones 2011). A change in perceptions of (in)security has occurred, as the threat of a major nuclear conflict between superpowers has been replaced by other threats (Bigo 2006). These are transnational in essence and include a wide range of issues, from pandemics and environmental disasters to piracy, terrorism, and organized crime. The latest in particular has become a great concern. As Bigo $(2006,387)$ points out, "War between states [is] less plausible, but crime [is] evolving and threatening the state and the identity of societies."In this context, critical approaches have emerged to challenge traditional security studies, of which the securitization framework 
developed by the Copenhagen School has been particularly influential (Williams 2003, 511).

Securitization has been defined by Buzan, Wæver, and de Wilde (1998) as an inter-subjective and socially constructed process, through which an issue is presented as posing an existential threat to a designated "referent object," requiring emergency measures and justifying actions outside the normal bounds of political procedure. Securitization typically works in two stages: 1) the enactment of a "securitizing move" targeting a specific "audience," and 2) the audience's approval of the countermeasures. In order to ensure successful securitization, "facilitating conditions"-i.e., particular features of the issue itself and its context - are put forward by the "securitizing actors" (ibid., 23-25). Indeed, while security cannot be reduced to the existence of objective threats, empirical considerations provide resources upon which actors may draw in securitizing a given issue (Williams 2003, 514). Such a discourse usually relies on a constructed dichotomy, in which the referent object-usually the state, the nation, and/or the people-are portrayed as "Self," and the threat as "Other" (Hansen 2006; Herschinger 2011).

The securitization framework has been criticized for a number of reasons, notably because of its exclusive emphasis on discourse (McDonald 2008; Jones 2011; Williams 2003), as opposed to practice, and for its Eurocentrism (Caballero-Anthony and Emmers 2006; McDonald 2008). The latter has led a growing number of scholars to recognize the fundamental importance of context in securitization (McDonald 2008; Balzacq 2005). Some have begun to extend its use to the analysis of non-Western contexts, both national and regional, and to adapt the framework in the light of these case studies. Because Southeast Asia has been increasingly recognized as hosting a particularly wide spectrum of security threats, it has attracted considerable attention in recent years (Emmers 2003; Caballero-Anthony and Emmers 2006; Caballero-Anthony 2008; Tan 2006). Still, extended analysis on a specific issue, and its implications for the practice of international relations within regional arrangements other than the European Union especially, are notoriously rare (Jones 2011; Haacke and Williams 2008). This article's main objective is to contribute to this growing literature by extending implications drawn from the Philippines' case to its wider regional context, and to show that the securitization process taking place in the Philippines on drug trafficking has regional ramifications, which may facilitate the progress of multilateralism in Southeast Asia. 
Following the path inaugurated by scholars such as Mely Caballero-Anthony (2008), Ralf Emmers (2003), Jürgen Haacke (Haacke and Williams 2008), Lee Jones (2011), and others, we first consider a number of elements that have to be taken into account before using the securitization framework for an analysis on drug trafficking in the Philippines and Southeast Asia. We adopt the assumption made by several of the aforementioned authors according to whom securitization is best conceived as a continuum, instead of a sudden securitizing move, through which an issue is gradually shifted from being considered an apolitical problem to its successful securitization, both through the acceptance of the "securitizing move" by the audience and the following enactment of extraordinary measures (Haacke and Williams 2008, 809; McDonald 2008; Williams 2003).

The paper will firstly examine the facilitating conditions put forward by securitizing actors in order to ensure a successful account of drug trafficking as a security threat in the Philippines. The next section will focus more extensively on the securitizing move $^{2}$ by national authorities-i.e., state officials, high representatives of national counter-trafficking agencies, officials from custom services, the police, the army, etc. - which is oriented towards a certain aspect of the threat: the recruitment of female drug mules. The third part of the paper will link this specific trend with a wider securitization process regarding drug trafficking emerging throughout the region. ${ }^{3}$ By introducing inputs from the cases of Thailand, Indonesia, and, to a lesser extent, Malaysia, this section will demonstrate that these countries present similarities with the Philippines as to how they officially deal with the issue of drug trafficking, and examine the potential impacts on interstate cooperation against security threats.

The analysis of what is underway in the Philippines regarding the framing of drug trafficking by national authorities reinforces the relevance of this view of securitization as a process. It does not imply that the process under scrutiny has to have already, or ever, lead to successful securitization, only that this framework is useful to think both about how the official discourse is elaborated and how countertrafficking policies are actually implemented. Also, readers will note that our research focuses much more on the first stage of the securitization process, i.e., the move by "securitizing actors."While we also analyze counter-trafficking measures implemented following the securitizing move, the receptivity of the audience, whether internal (political elites and other relevant actors in the decision-making 
process) or external (public opinion), is not a primary concern here, mainly because of a need for concision, but also partially because of the lack of transparency in the decision-making process in the countries under study, in comparison to cases that traditionally constitute the bulk of the research issued by the Copenhagen School.

The securitization process under scrutiny has been mainly translated through official communication, both written and declaratory, issued by national governments and ASEAN, and consequent policy initiatives. The media have played a significant role in relying such statements and have actively contributed to shed light on the specific aspects of drug trafficking in the Philippines and neighboring countries that have attracted official concern. Extensive interviews were also conducted with representatives of national and international countertrafficking agencies operating within Southeast Asia to improve our understanding of the specifics by which securitizing actors construct drug trafficking as a security threat. ${ }^{4}$

\section{FACILITATING CONDITIONS: DRUG TRAFFICKING IN THE PHILIPPINES}

The actual modalities of drug trafficking in the Philippines, and the region in general, that were the subject of official attention in recent years must first and foremost be brought to light in order to better understand the securitization process that is taking place simultaneously.

The most widespread drug of use in the Philippines has been crystal-methamphetamine, since manufacture operations have been installed during the 1990s by the yakuza, who fled crackdowns by the Japanese government (United Nations Office on Drugs and Crime [UNODC] 2011a, 113; Kaplan and Dubro 2003, 223-76). So-called "Ethnic-Chinese" gangs then allegedly took over control of the drug trade at the end of the 1990s. They were controlling drug exports from the Philippines, an easy destination for convoys carrying ephedrine, which is the main ingredient for the production of methamphetamine, from the People's Republic of China (PRC) and Taiwan to other countries in the region (Dupont 1999, 447; Lintner 2003, 3-5). Crystal-methamphetamine trafficking thus continues to be the main target of counter-trafficking operations in the Philippines and neighboring countries. 


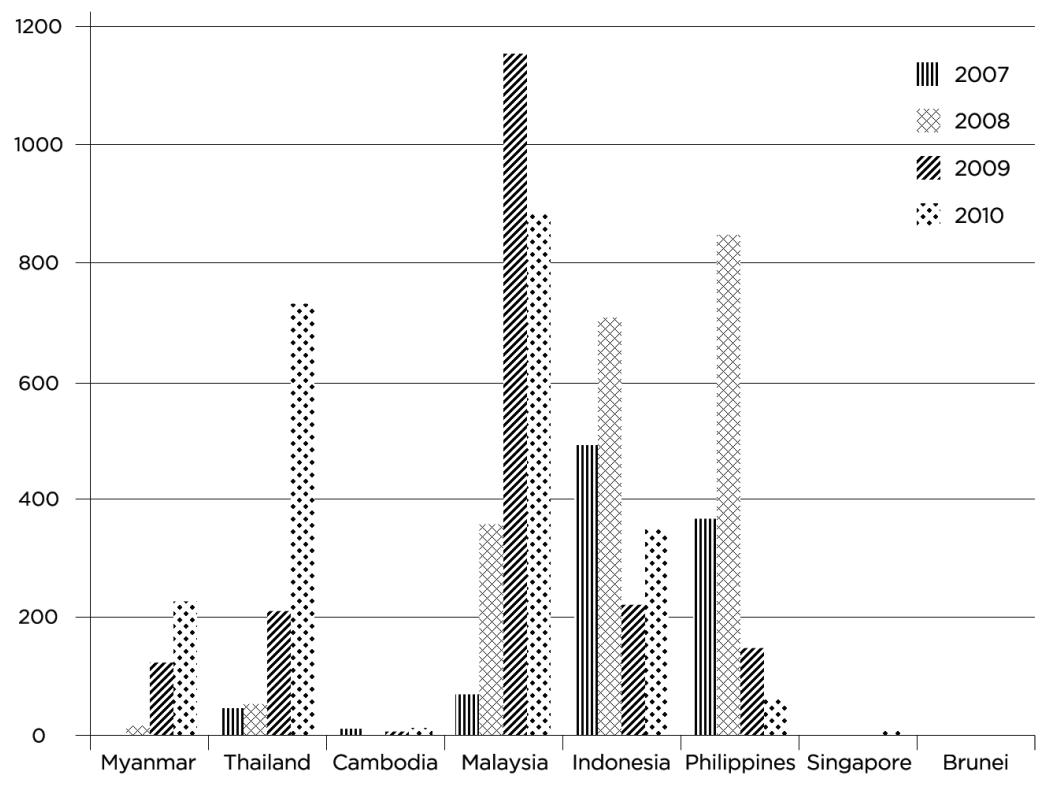

Figure 1. Crystal-meth seizures (kg) in Southeast Asia, per country, per year (UNODC 2011a). No data available for Laos and Vietnam.

While seizures culminated around 2008, a trend observed in most countries of the maritime sub-region of Southeast Asia, manufacture has been reported in the Philippines much earlier than in neighboring countries. The Philippine Drug Enforcement Agency (PDEA 2004) reports that its teams first discovered local manufacture facilities in 1999. According to the UNODC, large-scale production dates back to 2002. Between then and 2010, counter-trafficking authorities declared having successfully dismantled 72 laboratories.

There has been a shift from large-scale production to small-scale kitchen-type labs in recent years. In addition, signs of an increasing tendency to compartmentalize production, in different steps and locations, show that the search for manufacture sites is becoming more difficult for the authorities and allows corrupt agents to be more efficient in preventing seizures by tipping off alleged traffickers. While there have been many press reports on the implication in drug trafficking of local clans with extensive ties with the authorities, international counter-trafficking agencies repeatedly state that primary organizers and financers remain "Ethnic-Chinese" transnational organized crime groups, at least for methamphetamine trafficking (Bureau of 
International Narcotics and Law Enforcement Affairs [BINLEA] 2011 369; UNODC 2012, 117).

Other drugs such as heroin and cocaine are also present in considerable amounts in the Philippines. West African syndicates operating worldwide with ramifications throughout the region are known to control such activities, and national reports indicate that they have been particularly prone to recruiting women as drug mules. Official declarations also show that they seem to be gradually shifting to crystal-methamphetamine trafficking and that they rely increasingly on the Philippines as a hub for distribution in neighboring countries (BINLEA 2009; PDEA 2011; UNODC 2010, 2011a, 2012; Observatory on Illicit Trafficking 2011). Cannabis is also reportedly produced in large amounts in the regions of Luzon and Mindanao (PDEA 2010; BINLEA 2011, 457).

The use of human couriers to carry drugs is not limited to methamphetamine trafficking. But it must be understood that the drastic increase in the recruitment of mules is concomitant to the growing transnational character of drug trafficking in the region, an especially important feature of trafficking in synthetic drugs. The increasing number of Filipino nationals, especially overseas Filipino workers (OFWs), being arrested while carrying crystal-meth is a matter of great concern for national authorities (BINLEA 2011, 457). The PDEA $(2011,13)$ stated that 678 Filipino nationals had been arrested in other countries in 2010, 89 of which being on death row at the time the report was issued. According to official statements, these numbers point to a growing tendency among TCOs to rely on mules from manufacturing countries to ensure international transshipment of narcotics. This phenomenon has been the main subject of the securitization process that is taking place in the Philippines. The origin of this rise, according to the Philippine authorities, lies in the growing presence of West African Drug Syndicates (WADS) in the region, who typically rely on this mode of operation as it is well adapted to their predominant use of air transport.

The use of drug mules, especially women, is systematically linked with the greater issue of transnational criminal networks by the authorities. But there are also a certain number of indicators showing that a wide number of local criminal organizations participating in drug trafficking, among other activities, are operating inside the Philippines. The PDEA acknowledged that through the ASEAN Inter-Parliamentary Assembly (AIPA) Fact Finding Committee, 
which stated that 259 "local groups" were neutralized by national agencies' operations in 2010 (AIPA 2012). However, official reports indicate that the narcotics trade in the Philippines is embedded in transit routes crossing the entire region and controlled by regional players that facilitate the drug flows within and out of the country, sometimes employing local clans mainly to control production sites and trafficking within the country, while they assume the role of transnational brokers (Vellema et al. 2011, 303-4). Moreover, as local groups typically operate within national borders, the need to avoid suspicion is less systematic than when the crossing of borders through customs and checkpoints is involved. The recruitment of locals by traffickers of foreign origin working for TCOs to carry drugs across borders is seen as an effective way to limit the proportion of seizures and arrests from national authorities, as racial profiling is common and officially acknowledged (Agence France-Presse [AFP] 2012).

These facilitating conditions lead the authorities to elaborate a discourse that focuses on specific aspects of the drug trade in the Philippines, which are coherent with a general tendency to describe the threat as external to the region, and to implement counter-trafficking initiatives accordingly.

\section{THE RECRUITMENT OF WOMEN AS DRUG MULES}

The recruitment of women through the Internet or personal contacts by transnational organizations is a growing concern. The PDEA makes a point of repeatedly stating that out of the $678 \mathrm{drug}$ couriers arrested in foreign countries during 2010, 425 were women. This number still contrasts heavily with the national statistics showing that 84 percent of the inmates classified as "drug personalities" in 2010 were men (PDEA 2011,13), but the percentage of women convictions related to drug matters continues to rise in the region. Official reports assess that women are being wooed into relationships with foreign nationals who then exploit them as drug couriers with or without them knowingly carrying drugs. National authorities in the Philippines have thus been especially prompt in orienting the security discourse about drug trafficking on the use of Filipinas as mules by TCOs and the necessity for the government to protect them.

The securitizing discourse on drug trafficking in the Philippines has been innovative in comparison to other Southeast Asian countries. 
National authorities in the region usually present an undifferentiated category comprised of users, pushers, and mules, which account for most arrests, all assimilated under the label of "drug trafficking" and targeted as parasites to the morals of the nation, a privileged referent object regularly linked to the state. But the Philippine government has developed an extensive plea for mercy focusing on mules as victims instead of mere culprits. They consequently introduced a new category of drug personalities that is still rarely used in other national discourses: “recruiters" (Lesaba 2011; Sauler 2012).

An extensive analysis of press reports dating back to 2003 shows that mules are usually identified as "drug traffickers" by the authorities and the media of most countries, while the Philippines remain a noticeable exception. The Philippine government and its agencies will use very different qualifications when speaking of drug mules, who are presented as "helpless individuals" in need of "rescue," "migrant workers ... falling prey to the lure of drug syndicates" that commit the "heinous crime" of recruitment (AIPA 2012,2). This construction of a fundamental dichotomy between drug traffickers (including recruiters) versus drug mules has no equivalent in other countries yet. National authorities of most Southeast Asian countries prefer to include mules in a wider "drug traffickers" category distinct from "the nation" as a traditional referent object, i.e., the target of the alleged security threat (Buzan et al. 1998, 21-22). While it still remains marginal in neighboring countries, in the Philippines, a particular subjectivity of the female drug mule as a "victim," stressing out her need for protection from harm (Fleetwood and Haas 2011, 198), is prevalent in both discourse and practice.

There have been undeniable signs since 2010 that female drug mules convicted in foreign countries were worrying the Filipino authorities, who then began to stress the fact that such a tendency had been identified as dating back to 2007 (GMA Nerws 2011). The PDEA indeed identified the recruitment of drug mules for the first time in its 2008 annual report: "Recent developments revealed the increasing involvement of Filipinos as 'mules' in transporting illegal drugs abroad. These Filipino 'mules' are tightly monitored by the West African Drug Syndicates (WADS) during the drug run bound for China. The mules usually get in contact with the WADS in exit points where they were given instructions. Meanwhile, the WADS escort the mules to facilitate entry to destination points. From 2001 to 2005, WADS employed male 'mules.'However, the successive arrest of male mules ... en route to the 
final destination point, compelled the WADs to change gear and begin employing female mules" (PDEA 2008, 15). This shift to female mules by the WADS, according to counter-trafficking authorities, is linked both to a desire to avoid suspicion from the authorities, as local women allegedly attract less attention than their male counterparts, and the impression—shared by male officials— that they are both dispensable and more easily manipulated, especially when engaged in romantic relationships with drug traffickers.

Nevertheless, to our knowledge, this mode of operation was not publicized in the media as a pattern until 2010. The PDEA directorgeneral, Dionisio R. Santiago, declared in March 2010 that of the sixty-six nationals on death row in China at the time, fifty-three were women, and this information has been widely promoted by the media since (Segura 2010). Such considerations had led to the creation of a Drug Couriers Task Force under Arroyo's presidency the month before to "prevent the further victimization of Filipinos by international drug syndicates" (Philippine Star 2011a). Press statements following the creation of such a mechanism focused on the necessity for the government to protect fellow countrymen (ibid.). Following the launch of this initiative, the Philippine Embassy in Thailand targeted West African drug syndicates as operating large-scale recruitment of Filipino women as mules (OFW Nerws Worldwide 2010). But it is a specific case that permitted a rapid shift of the issue to top priority governmental concerns and contributed the widespread focus on women, with the approval of the public opinion. In 2011, three Filipino drug mules, including two women, who were facing death row in China for smuggling heroin in the country, attracted a wide movement of sympathy in the Philippines from civil society (Sun Star 2011). There was a widespread assumption in the country that Sally Ordinario-Villanueva, Ramon Credo, and Elizabeth Batain had been duped by transnational criminal syndicates. The fact that they came from poor families was also emphasized regularly both by the media and government officials, especially President Benigno Aquino III, who repeatedly asked its Chinese counterparts for clemency. The media covering of Sally Ordinario-Villanueva's last moments with her relatives was especially emotional, stressing her responsibility as a mother and breadwinner for her poor family in addition to portraying her as a victim of manipulation (AFP 2011). This contrasts heavily with the subjectivity employed by the media and the authorities to describe recruiters as in charge and immoral. It must also be noted that 
press reports generally stress the fact that recruiters are predominantly male, but do not make a distinction when women are involved in recruitment, as was the alleged recruiter of Sally Ordinario-Villanueva, Tita Cacayan (Sauler 2012).

Socio-economic difficulties resulting from gendered dimensions of poverty, as well as coercion through interpersonal threat, are stated by research on drug mules as important factors explaining the active involvement of women in the drug trade (Fleetwood and Haas 2011, 197). However, according to the United Nations (UN) Commission on Narcotic Drugs (2011), there is an important lack of data on the circumstances and consequences that lead women to getting involved in drug trafficking, which renders the production of a comprehensive analysis on this quite difficult. Some NGOs have been focusing on this question. Gabriela Women's Party (2012), the party list of the feminist NGO network Gabriela, publicized conclusions of the PDEA and the Department of Foreign Affairs (DFA) about the rise in enrollment of female OFWs as drug mules in order to criticize governmental policies on labor export. However, official reports in the Philippines and neighboring countries, when mentioning specific circumstances, typically point to superficial speculations, are way more interested in focusing on the role of TCOs, and usually deprive women of agency in their own involvement. Philippine authorities are targeting recruiters, and failing to implement effective pre-emptive socio-economic measures to reduce women's incentives to work as drug mules in a situation of crisis and debt.

In February 2011, the Department of Justice, acting on behalf of President Benigno Aquino III, ordered the National Bureau of Investigation (NBI) to reinforce its commitment to rid the country of criminal syndicates recruiting OFWs as drug mules. In subsequent declarations, government representatives made a clear link between the activities of so-called "WADS," especially Nigerian nationals, and the recruitment of women as drug mules (Inquirer 2011). A national PR campaign was also launched by the PDEA and the Philippine Information Agency to warn against the consequences of being recruited as a drug courier. The posters stating "Don't even think about it!" showing a black silhouette carrying drugs in its stomach did not target women especially. The link was made through official statements surrounding the campaign, specifically focused on the difficult socio-economic conditions of Filipinas unable to find jobs as maids in a time of economic recession as the main explanation for an alleged rise in convictions of drug mules. 


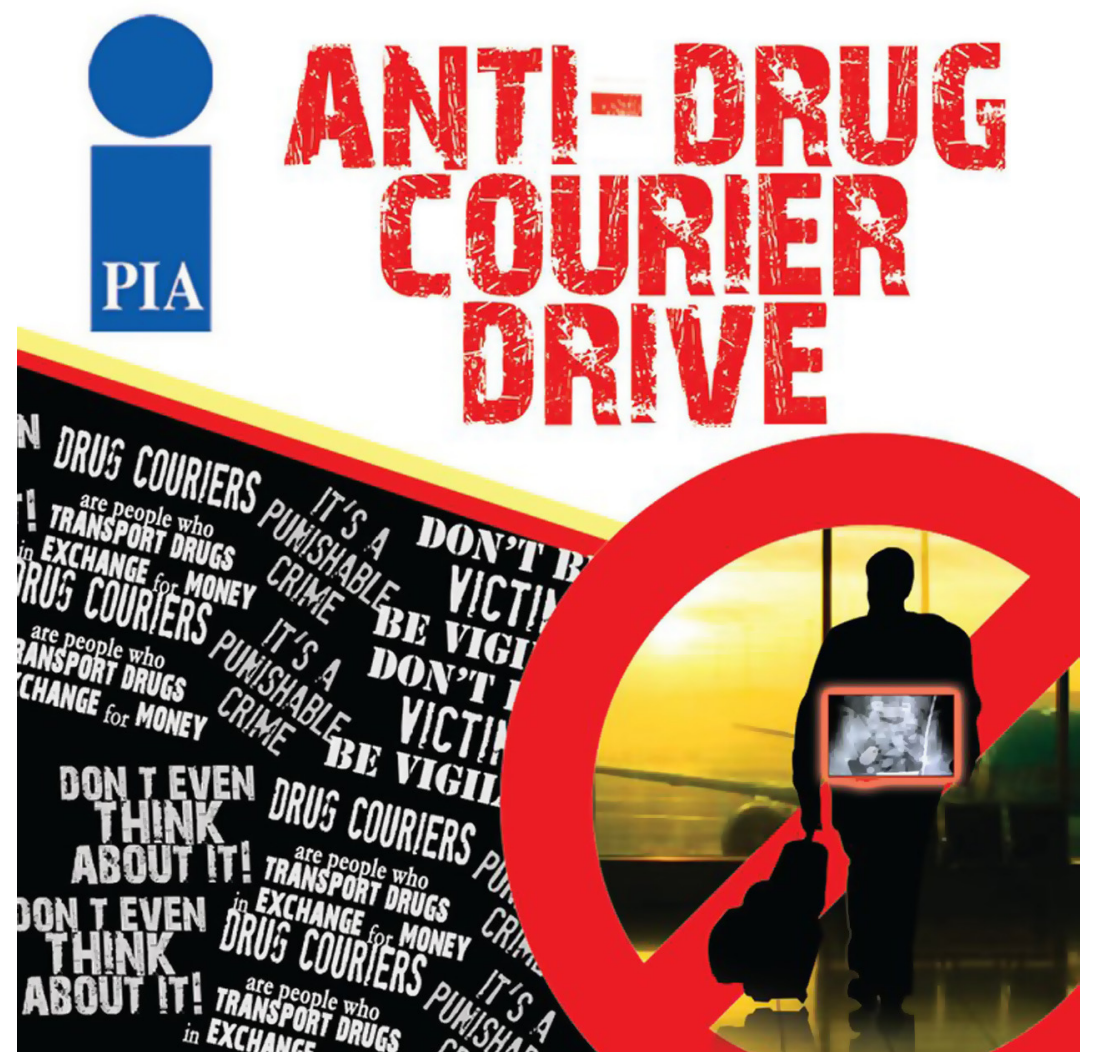

Figure 2. Anti-drug couriers PR campaign (Anti-Drug Courier Drive 2013). 
One of these statements came from Ed Malaya, then spokesperson of the DFA, and it perfectly sums up the securitization process going on: "there appears to be a specific targeting of our Filipina women by international drug syndicates to be used as drug mules" (Elona 20 11). It is particularly interesting that women are often perceived as victims of manipulation by recruiters, lured into marrying men that then either conceal drugs into their luggage without them knowing, or pressure them into voluntarily carrying drugs (Lesaba 2011). A couple of months after the DFA, Jose Gutierrez Jr., director of the PDEA, issued the following statement: "The series of arrest of female drug personalities, both local and foreign nationals, indicates that the illegal drug trade is no longer a man's world. ... Because women are less prone to suspicion by law enforcers, drug syndicates have exploited this inherent characteristic" (Elona 2011).

The most evident manifestations of the securitization process, as stated before, immediately followed the execution of alleged drug mules Sally Ordinario-Villanueva, Elizabeth Batain, and Ramos Credo in China on March 30th, 2011 (AFP 2011). President Aquino declared countering drug trafficking a top priority amidst the surge in the recruitment of OFWs as drug mules (Avendaño 2011; Philippine Star 2011d). At the beginning of April 2011, the DFA pleaded for the launch of an all-out war on "international drug syndicates, which have increasingly victimized Filipinos as drug couriers" (Philippine Star 2011c). According to these statements, the PDEA ought to be in charge of leading a coalition of national agencies including the Bureau of Immigration, the national police, the Bureau of Customs, and the NBI (ibid.).

A year later, the recruitment of drug mules is still stated as a top priority by the PDEA and serves to justify calls for greater budgets and extraordinary measures. The most recent example of this is a statement issued by PDEA director-general Jose S. Gutierrez Jr. seeking an amendment of the anti-wiretapping law, Republic Act no. 4200, in order to include drug trafficking in the list of crimes for which wiretapping may be allowed, with the objective to trace alleged ring leaders (Yap 2012). The PDEA uses the 2011 International Narcotics Control Strategy Report to stress the necessity to remedy the lack of resources allowed to counter-trafficking agencies in the Philippines. More recently, the AIPA (2012) reported that "restrictive laws that prevent law enforcers from identifying the drug kingpins" were one of 
the main "stumbling blocks in its anti-drug campaign," and called for the removal of "the financial constraints to wage an all out war against drug traffickers."

The focus on drug mules by the authorities must be seen as part of a general tendency to target the activities of TCOs from outside the region since the end of the 1990s (PDEA 2004, 2005, 2006, 2007). As explained before, drug trafficking in the Philippines is viewed as being embedded in regional networks whose main players are transnational organizations from China, Iran and West Africa, to which local groups are linked. But the alliances between TCOs and local clans or so-called "drug lords" are typically ad hoc, very fluid and difficult to ascertain (Dupont 2001), so one must be extremely cautious with sensationalist statements that describe transnational organized crime as a hierarchy of more or less important individuals and groups. Moreover, while extensive research on bossism in the Philippines suggests that local clans are implicated in drug trafficking among other criminal activities (McCoy 2009, xix; Sidel 1999, 135-36), these links are excluded from the official securitization process, which targets the role of transnational networks. An exception remains with insurrectionist groups from the southern Philippines, who are targeted by the PDEA and the media as important actors in crystal-methamphetamine trafficking and other substances (GMA News 2006; Philippine Star 2002).

Chinese syndicates from Hong-Kong, Taiwan, and the PRC have been singled out by Filipino agencies as the main players in drug trafficking within and outside the country. The authorities have increasingly reported alleged links with the Chinese diaspora and local criminal groups. According to the PDEA, drug production in the Philippines is mainly destined to the Chinese market, including Taiwan (Segura 2010). This clashes with numerous reports of local use, a wide range of intra-regional destination countries and the targeting of Filipino market by transnational groups from Iran and West Africa operating in Southeast Asia. Reports show that the use of local women as drug mules is more common in transit operations involving West African networks, whereas Iranian syndicates tend to rely more on Iranian nationals, both men and women alike. There have not been as many specific reports incriminating Chinese syndicates of using women as mules, but they are still targeted as such at least since March 2010, when statements from the PDEA linked the recruitment of mules to carry drugs to China with the operations of "Ethnic-Chinese" gangs. The PDEA director-general of the time, Dionisio R. Santiago, 
then stated, "In terms of drug trafficking, the Chinese are everywhere," explaining that the Philippines had become a regional hub for syndicates originating from Hong Kong, Macau, and Taiwan, as well as the southern Chinese provinces of Guangdong and Fujian. The launch of a national campaign to counter the recruitment of Filipino mules in April 2011 served as a justification for the simultaneous imposition of tighter guidelines by the Bureau of Immigration on the entry of Chinese and West African nationals, especially Nigerians (Philippine Star 2011b).

A number of press articles by Filipino media have reported arrests and seizures of shabu involving local drug "lords," "kingpins," and "bosses," but we must be careful with the use of such qualifications because they are eminently arbitrary and unreliable, especially when they come from counter-trafficking agencies facing suspicions of corruption and trying to justify their relevance through quotas. These articles rely on sensationalist information about specific localities, and rarely, if ever, make links with the global picture of drug trafficking in the Philippines in comparison to reports on TCOs. While they provide some information on the modalities of the phenomenon under scrutiny, they are therefore situated outside the discourse we are interested in. With the fragmentation of drug trafficking in recent years, it is especially challenging to distinguish scapegoats from genuine drug kingpins, who are most likely well protected by intricate links of patronage and corruption with the authorities (Sidel 1999; McCoy 2009). Thorough research on specific patterns of the informal economy in the Philippines since the end of the 1990s is needed, if we are to better understand the reasons why local clans are generally left out of the securitization process on drug trafficking.

A notable exception to this pattern is the denunciation by the authorities of the role of rebel organizations and ethnic-minority groups in cross-border criminal activities and drug trafficking as an endemic phenomenon in peripheral regions, a focus that has served as a justification for numerous wars on drugs and other law enforcement campaigns. This has been the case in the Philippines (Dupont 2001, 183, 201; Dick 2005, 271), where Abu Sayyaf and the Moro Islamic Liberation Front (MILF) are targeted by national authorities implicated in drug trafficking (BINLEA 2009, 92; UNODC 2009, 183), ${ }^{5}$ but also in Cambodia, Indonesia, Laos, Myanmar, Thailand, and Vietnam. 


\section{A REGIONAL DISCOURSE ON DRUG TRAFFICKING: PROSPECTS FOR MULTILATERALISM}

The process underway in the Philippines presents a number of similarities with how drug trafficking is being presented by national authorities from neighboring countries. While the victimization of drug mules has been a central feature of counter-trafficking operations in the Philippines, a similar focus is also increasingly common in other Southeast Asian countries, notably in Malaysia,Indonesia, and Thailand. Whereas the so-called "CLMV" block (Cambodia, Laos, Myanmar, and Vietnam) continues to include mules in the hold-all category of "drug traffickers," the discourse taking place in the Philippines seems to have counterparts in neighboring countries, where the victimization of female drug mules is accompanying the implementation of countertrafficking initiatives both at the national and sub-regional levels. This trend is consistent with an overarching securitization process situated on a regional scale, according to which drug trafficking is framed as a foreign predation that is becoming prevalent throughout Southeast Asia, which can be conceived as a "security constellation" (Buzan and Wæver 2009, 256). It is representative not only of widespread but independent national security concerns, but also of ASEAN's increasing efforts to target transnational security issues since the middle of the 1990s.

\section{THE VICTIMIZATION OF DRUG MULES IN NEIGHBORING COUNTRIES}

Indonesia shares with the Philippines its concern over the recruitment of women as mules by WADS. Numerous press reports in 2011 stress that both Indonesian and Filipino women are operating as couriers within Indonesian territory. A particular case attracted attention from the media in 2011: Custom officers arrested a pregnant woman at Bali Ngurah Rai International Airport for "allegedly attempting to smuggle 324 grams of crystal-methamphetamine by swallowing it." Indonesian authorities declared that it was a new mode of operation, because until then pregnant women were less likely to be subjected to $\mathrm{X}$-ray scans (Erviani 2011). But the recruitment of female drug mules has been the focus of media coverage earlier than that. In June 2010, the National Narcotics Agency (BNN) launched a program to prevent 
Indonesian women from enrollment as drug couriers. The chief of the agency, Gories Mere, stated that "drug syndicates use women couriers because it is easier for women to get through entry points," and that their numbers had increased since 2008. While stressing that, as in the Philippines, women were lured by marriage proposals from drug dealers posing as potential husbands who then pressured them into acting as mules, the emphasis on victimization is less evident than in the Philippines. The BNN explains the phenomenon mainly by a lack of education and awareness by women of the consequences of drug trafficking (Jakarta Post 2010). In August 2010, the Ministry of Labor manifested its concern over the situation of Indonesian drug mules facing death row in Malaysia (Kompas 2010).

Malaysian authorities began to emphasize the recruitment of Malaysian women as drug mules as a pattern for international drug syndicates in April 2011, about the same time the similar securitization process culminated in the Philippines. Public opinion movements of sympathy over drug mules arose with the case of Yong Vui Kong, a Malaysian national facing death row in Singapore in 2011. Representatives of the Ministry of Foreign Affairs repeatedly declared in April 2011 that the recruitment of single mothers and female university students by drug trafficking syndicates, especially from West Africa, through social networks on the Internet, was becoming more common (New Straits Times 2011a, 2011c). WADS' recruitment of local drug mules was the subject of calls in 2012 for the enhancement of interstate cooperation between the Malaysian authorities and their counterparts in neighboring countries (New Straits Times 2012a). However, as is the case in Indonesia, women tend to be less victimized by the authorities who repeatedly express suspicions over pleas that they did not know they were carrying drugs. At a press conference in December 2011, Narcotics Criminal Investigation Department director, Datuk Mohd Noor Rashid Ibrahim, declared that "the lure of money and luxurious lifestyle promised by syndicates were among the factors women in the country were willing to become drug mules." In a more recent declaration, the Kuala Lumpur International Airport customs director Datuk M. Govinden stated that there had been an increase in the number of local women convicted for carrying drugs in 2011. According to him, drug syndicates used local women from age 19 to 20, and lured them with expensive goods (New Straits Times 2012b). In general, Malaysian authorities seem to be convinced that the women caught carrying drugs were perfectly aware of doing so and 
were driven by greed (New Straits Times 2011b). Despite the public sympathy that such cases sometimes attract, the director of the Federal Narcotics Department made that point very clear in an interview in February 2012 (Ramli 2012). 2012 witnessed an increasing number of statements by the authorities stressing recruitment of female drug mules by WADS as the most recent mode of operation of drug traffickers in the country (Shi-Ian 2012).

Thailand is probably the country where the discourse on women drug mules is the most similar to that of the Philippines. In February 2011, counter-trafficking agencies began to express particular concern over WADS recruiting Thai women as drug mules. The director of the Narcotics Suppression Bureau, Atithep Panjamanond, reported numerous cases of African men "tricking" Thai women into marrying them and then manipulating them in carrying drugs. The discourse focuses on the difficult socio-economic conditions of the women recruited and serves as a justification for the reinforcement of custom regulations over the entry of individuals from West African countries (Bangkok Post 2011). What is particularly interesting in such reports is that while the press coverage of drug mules arrests is extremely important in Thailand, only cases of Thai women targeted by male West African traffickers have been identified as a pattern, and used as a pretext for generalizations over the wider issue of drug trafficking between 2009 and 2012. These considerations have led Filipino and Thai authorities to reach an agreement on the reinforcement of bilateral information sharing to stop international drug syndicates from recruiting drug couriers in the two countries (Lee-Brago 2011).

The recruitment of local women as drug mules by transnational syndicates has been a focus of a wider securitization process common to most, if not all, components of the region. This focus was more recurrent in the Philippines, where national authorities have also stressed a particular dimension of the problem: the victimization of recruited women, with an emphasis on the difficult socio-economic conditions they face. The Philippines singled out drug mules not as representatives of the threat itself, but as part of the threatened. This is indeed part of a regional tendency to frame drug trafficking as an external threat, while insiders that could be assimilated to that threat are either ignored in the discourse, defined as outsiders, or included on the victim side when possible.

In other countries facing a similar phenomenon, most notably Malaysia and Indonesia, national authorities express suspicions and 
stress the pursuit of luxury as the main motive of women enrolled as drug mules. But a discourse very similar to that of the Philippines emerged simultaneously in Thailand, albeit in a more limited fashion. This has led both countries to improve bilateral arrangements based on the perception of common interests. This development is far from anecdotal and indicates that the harmonisation of security discourses supplemented by national counter-trafficking initiatives compatible across countries may lead to increasing cooperation.

\section{DRUG TRAFFICKING AS A FOREIGN PREDATION: A WIDER SECURITIZATION PROCESS}

We have now established that the victimization of female drug mules by transnational criminal networks has increasingly attracted the attention of national authorities both in the Philippines and neighboring countries. We now turn to an assessment of how this tendency is linked to other elements characterizing the way national governments in the region frame drug trafficking,

As indicated above, the general orientation of the securitization process is to present drug trafficking as an external predation. The recruitment of women as drug mules is singled out as the main problem associated with the presence of TCOs from non-ASEAN countries, mainly China, Iran, and Nigeria. This trend is arguably the main feature of the official discourse on drug trafficking taking place in the region, but it is complemented with two additional elements: the imputed responsibility of ethno-cultural minorities, and the concern that drug trafficking serves as an important component of the funding of secessionist insurrections. The distinction between "Self" and "Other" is prevalent in every one of these three elements, and the threat is understood as primarily targeting national sovereignty and territorial integrity while including a connotation about identity.

\section{Drug Trafficking as a Source of Funding for Insurrectionist Groups}

The ongoing presence of insurrectionist groups in Aceh (Indonesia), Southern Thailand, and Mindanao (Philippines) has shaped the official discourse on drug trafficking as well as counter-trafficking measures. 
Again, the focus on links between organized crime and armed insurrections in the margins of these countries by national authorities is linked to facilitating conditions. It has been emphasized by scholars that the presence of drug production sites increases the duration of conflicts (Cornell 2005, 753; Ross 2005, 53) and that, in Southeast Asia especially, "drug traffickers are [increasingly] allying themselves with separatist ... groups, serving as 'cash cows' in return for protection and access to paramilitary resources. In some cases, the drug traffickers and insurgents are one and the same" (Dupont 2001,194). Moreover, an extensive literature on the "crime-terror nexus" has shown that terrorist groups tend to rely on drug trafficking, among other illicit activities, to finance their operations (Makarenko 2004). Accordingly, terrorism and organized crime have been regularly amalgamated under the broad category of "transnational crimes" by ASEAN since 1997 (Haacke and Williams 2008, 795-99). Governmental agencies from Thailand, Indonesia, and the Philippines have put these considerations at the forefront of their official discourse on drug trafficking, applying them to the groups operating on their respective national territories.

Drug trafficking and organized crime is endemic in Southern Thailand, where control by the national government is considerably limited by the presence of secessionist groups, especially in the three provinces of Pattani, Yala, and Narathiwat. Since 2001, when Thaksin Shinawatra came into power, the Thai government has made a point to focus on drug trafficking activities by the insurgents while playing down their political motivations (Liow and Pathan 2009, 4). This has led the authorities to include national security issues specific to the South under nation-wide concerns about organized crime and related counter-trafficking initiatives, notably the especially violent 2003 "war on drugs," during which 2,500 were killed, including a wide proportion of innocents (The Nation 2007). More recently, high representatives of the military and police units in charge of security in the South released common statements about their suspicions that Muslim secessionist groups and drug traffickers have increased the level of their collaboration. Officials have expressed specific concerns about the systematic targeting of policemen by armed insurgents since February 2011, which was perceived as the undeniable sign that drug kingpins with access to sophisticated information on the whereabouts of policemen were implicated. According to them, the most plausible explanation was that a pact had been contracted to ensure that in exchange for information and funding by drug traffickers, the insurgents 
would aim at strategic targets linked to counter-trafficking operations instead of random ones. However, while government representatives claim that these links have been long known, no indication of the sort has yet been confirmed by the independent experts interviewed apart from the fact that the respective spheres of activity of each group are difficult to distinguish in such a context.

Indonesian media have repeatedly reported that drug trafficking is endemic in Aceh, systematically linking such information with the ongoing political instability in the area. The police have recently renewed concerns about the links of remnant Acehnese militants with the Jeemah Islamiyah (JI), a terrorist organization allegedly responsible for the Bali bombings of 2002 and 2005 (Hasan 2010). According to information issued by Indonesia authorities, the JI is implicated in extensive drug trafficking operations (Praginanto 2009; Saragih 2011).

The Philippines is probably the country where official concerns about the links between organized crime and terrorism are the most explicit. As noted above, the Philippine government and international counter-trafficking agencies agree that Abu Sayyaf and the MILF were using shabu as one of their primary sources of funding (UNODC 2009, 183; BINLEA 2009, 92). ${ }^{6}$ The BINLEA of the US Department of State, relying on information provided by national countertrafficking agencies in the Philippines, reported in 2009 that drug traffickers affiliated with Abu Sayyaf were the main providers of methamphetamine within the country and have developed extended links throughout the region. According to the same report, Abu Sayyaf is also implicated in providing protection to manufacture sites (BINLEA 2009, 92).

\section{Ethno-Cultural Minorities and the Distribution of Narcotics: The Case of Thailand}

The distinction between insiders and outsiders is typical of every national discourse on drug trafficking in the region. It has already been noted that officials in the Philippines expressed numerous concerns about the implication of people from Mindanao in the drug trade, and that there was a recurrent ambivalence in official statements about the implications of "Ethnic-Chinese" groups as well, often without further distinction between Chinese nationals and individuals from the diaspora. In Indonesia, an editorial has recently issued a call 
to the nation to combat "a massive invasion of drugs," focusing on the culpability of individuals of foreign origin (Jakarta Post 2011). Nevertheless, the country where the specific targeting of minority groups as implicated in drug trafficking is the most extensive among those under study remains, undoubtedly, Thailand.

Calls to the nation were a main characteristic of Thaksin Shinawatra's official declarations during the 2003 war on drugs, during which the targeting of minority groups from the North was especially important. The wide perception of yao and b'mong populations as responsible for social evils associated with drugs dates back to the 1970s and the prime of the heroin trade from the Golden Triangle (Lyttleton 2004, 914). Drug dependence among such groups has also been the focus of numerous articles during the 1990s, being interpreted by the media as the symptom of a great shock that the hill tribes were supposedly facing in the context of rapid economic development and social progress (Bangkok Post 1993, 1994a, 1994b, 1996; The Nation 1993). This depiction is reminiscent today with the difference that Thai authorities now target minority groups as active participants in the distribution of synthetic drugs from the Golden Triangle (Bangkok Post 2010), as was explicitly expressed during interviews conducted in April 2011 with high representatives of the Office of Narcotics Control Board.

\section{IMPLICATIONS FOR INTERSTATE RELATIONS WITHIN ASEAN}

The previous section has emphasized the linkages between different aspects of a wider securitization process of drug trafficking focusing on the responsibility of outsiders in the drug trade. The recruitment of female drug mules by TCOs and the associated focus by national authorities from the Philippines, Thailand, and Indonesia can be interpreted as part of a coherent representation of drug trafficking as a foreign predation. This also has implications for interstate relations within the region. The focus on TCOs, minorities, and insurgents has been the pretext for improving the range of counter-trafficking initiatives, both bilateral and multilateral, among ASEAN countries, while avoiding putting the blame on fellow member states. The authorities not only focused on the presence of Chinese, Iranian, and West-African TCOs in the region, but have also been especially 
careful, when the responsibility of another member state could not be ignored, to avoid specifics while preferring vague references to a "neighboring country." This deliberate vagueness is in line with diplomatic norms characteristic of the so-called "ASEAN way," and is perfectly compatible with the progress of cooperation on such issues. It has allowed a continued participation of member states' representatives in specific meetings and working groups on transnational crime.

Moreover, counter-trafficking mechanisms have also been increasingly formalized over the years. In particular, a review of reports by the Dialogue and Research Monitor (2003, 2007, 2008) shows that while trafficking in synthetic drugs was becoming an increasingly alarming trend for national authorities in most of Southeast Asian countries, transnational organized crime was simultaneously moved from informal to formal discussions at the regional level. The 2007 report states, "It appears that there are regional mechanisms in place that are moving forward steadily to address these issues, such as ... the ASEAN and China Cooperative Operations in Response to Dangerous Drugs (ACCORD), the meetings of the ASEAN Senior Officials on Drugs, and the Senior Officials Meeting on Transnational Crime and its working group on narcotics" (Dialogue and Research Monitor 2007). ASEAN Senior Official on Drugs (ASOD) 20092015 Action Plan currently defines regional cooperation against drug trafficking. This initiative represents an incremental process dating back to 1972, when heroin production peaked in the Golden Triangle (Emmers 2006, 9). Since the inclusion of Myanmar by ASEAN in 1995, the depth of relevant mechanisms and the pace by which regional initiatives are implemented have steadily increased (Emmers 2006, 16; Haacke 2009, 429; ASEAN 1997). The Plan of Action for a Drug-Free ASEAN in 2015 (ASEAN 2000) and the Declaration on ASEAN Concord II (ASEAN Secretariat 2009) include explicit commitments to multilateral cooperation against transnational crime.

Recent developments in the illicit drug trade, among other nontraditional issues, have made governments traditionally reticent to multilateralism realize the necessity to increase cooperation with each other to face transnational security challenges. Further research is needed to reach a comprehensive understanding of the implications on regional cooperation of national authorities in Southeast Asia harmonizing their security policies around common interests. Systematic evaluation of the impact of non-state actors, especially epistemic communities, in shaping the agenda of interstate security 
cooperation against non-traditional issues, would be especially interesting. Security cooperation in Southeast Asia has been based on the growing perception of shared interests against common threats and may as well contribute to the formation of a regional identity among elites (Acharya 2009; Busse 1998). It remains to be seen if, and in what measure, such perception can help sustain the progress of regional integration in the following years.

\section{CONCLUSION}

It has been shown that a particular securitization process is taking place in the Philippines with regard to drug trafficking. The official discourse currently focuses on the recruitment of female drug mules by transnational criminal organizations. While this tendency is now shared by a growing number of states in Southeast Asia, the Philippine authorities have adopted a particular subjectivity of the women involved as victims, stressing the need for the government to protect them. This has led the authorities to add a sub-category to the encapsulating "drug traffickers," "recruiters." Accordingly, specific measures were implemented that target the enrollment of female drug mules by TCOs. This distinction has not yet appeared in neighboring countries, but there are increasing signs that point to a gradual harmonization of the framing of drug trafficking at the regional level, which guides the implementation of an increasing number of agreements, mechanisms, and practices of regional cooperation.

As Southeast Asia has been particularly affected by the rise of transnational organized crime after the end of the Cold War, the securitization framework developed is useful to understand how national authorities have been framing this issue as a security threat. The framing of drug trafficking in the Philippines has proved an especially interesting case study in this matter. Nonetheless, is also contributes to reinforce the relevance of a reformulation of securitization as a process instead of an endpoint, especially to increase its application to nonWestern contexts. 


\section{NOTES}

1 The author would like to acknowledge the contribution of the following individuals to the development of this paper: two anonymous reviewers, Steffen Jenson, Dominique Caouette, Julien Vallée, Clara Boulianne-Lagacé, Adrien Vallat, Béatrice Rea, Anne-Lise Sauterey, François Guillemot, and Eric Frécon.

The author would also like to acknowledge the support of the following organizations: the Observatory of Illicit Trafficking, the Research Institute on Contemporary Southeast Asia (IRASEC), the Institute of East Asian Studies (Université Lyon 2/ENS Lyon), and the Department of Political Science and the East Asian Studies Centre (University of Montreal).

2 While the securitization framework elaborated by the Copenhagen School focuses on the importance of the "speech act" by securitizing actors, we prefer the use of "securitizing move," which implies a broader definition of what constitutes discourse, including different types of political communication.

3 It is important to note that the recruitment of drug mules has recently reached a level of global concern, as the UNODC briefly reported in its 2011 World Drug Report, but with no mention of women being especially targeted (UNODC 2011b). Still, the adoption of the UN Resolution 52/1 "Promoting international cooperation in addressing the involvement of women and girls in drug trafficking, especially as couriers" and the subsequent report (UN Commission on Narcotic Drugs 2009, 2011) points out to a global securitization process that is linked to the growing presence of West African Drug Syndicates (WADS) and their prominent use of drug couriers, and is clearly informed by reports at the regional level of East and Southeast Asia (UNODC 2011a, 166). The global reach of the securitization process under scrutiny will not be the subject of this paper as it is only beginning to take place.

4 Interviews of drug mules and traffickers have not yet been conducted successfully by the author due to access limitations to potential interviewees, so the focus of the present article is on the framing of the issue by the authorities (and the media) and their interpretation of the motivations of individuals and groups implicated in the drug trade, complemented by insights from independent research on drug mules.

$5 \quad$ Among other articles, see Philippine Star 2002 and GMA News 2006.

6 Also see GMA News 2006 and Philippine Star 2002.

\section{REFERENCES}

Acharya, Amitav, 2009. Constructing a security community in Southeast Asia: ASEAN and the problem of regional order. Abingdon: Routledge.

Agence France-Presse (AFP). 2011. 3 Filipino drug mules executed in China. Inquirer, 30 Mar. Online, http://globalnation.inquirer.net/news/breakingnews/view/20110330328415/3-Filipino-drug-mules-executed-in-China, accessed 15 Jun. 2013.

2012. Philippines tightens watch on African arrivals over drug smuggling. Inquirer, 17 Mar. Online, http://globalnation.inquirer.net/29775/philippines-tightens-watchon-african-arrivals-over-drug-smuggling, accessed 15 Jun. 2013.

Anti-Drug Courier Drive. 2013. Facebook page. Online, https://www.facebook.com/ pages/Anti-Drug-Courier-Drive/189707434394681? ref=ts\&fref=ts.

ASEAN Inter-Parliamentary Assembly (AIPA) Fact Finding Committee. 2012. Progress report on the actions taken by the Philippine government to combat the drug menace, 8-12 Jul. D.I.Y. Yogyakarta, Indonesia.

ASEAN Secretariat. 2009. ASEAN political-security community blueprint. Jakarta: ASEAN.

Association of Southeast Asian Nations (ASEAN). 1997. ASEAN declaration on transnational crime. Manila, 20 Dec. Online, http://www.asean.org/5640.htm.

2000. Political declaration in pursuit of a drug-free ASEAN 2015. Bangkok, 13 Oct. Online, http://www.asean.org/644.htm. 
Avendaño, Christine O. 2011. Beating drug problem top priority, says Aquino. Inquirer 4 Jan. Online, http://newsinfo.inquirer.net/inquirerheadlines/nation/view/20110401328685/Beating-drug-problem-top-priority-says-Aquino, accessed 15 Jun. 2013.

Balzacq, Thierry. 2005. The Three Faces of Securitization: Political agency, audience and context. European Journal of International Relations 11(2): 171-201.

Bangkok Post. 1993. Development brings merchants of death to the highlands. 13 Jun.

- - 1994a. Change in lifestyle increases drugs use. 26 Jun.

-- . 1994b. Heroin plagues the hill tribes. 26 Jun.

- - . 1996. Hmong blamed for local woes - Officials: They steal jobs, are in sex trade. 25 Dec.

-- 2010 Few highs for drug busters. 3 Feb.

--_. 2011. Love, marriage, and drug mules. 14 Feb.

Bigo, Didier. 2006. Internal and external aspects of security. European Security 15(4): $383-404$

Bureau for International Narcotics and Law Enforcement Affairs (BINLEA). 2009. International narcotics control strategy report, vol. 1, Drug and chemical control. Washington, DC: U.S. Department of State.

2011. International narcotics control strategy report, vol. 1, Drug and chemical control. Washington, DC: U.S. Department of State.

Busse, Nikolas. 1998. Constructivism and Southeast Asian security. Pacific Review 12(1): 39-60.

Buzan, Barry and Ole Wæver. 2009. Macrosecuritisation and security constellations: Reconsidering scale in securitisation theory. Review of International Studies 35: 253-76.

Buzan, Barry, Ole Wæver, and Jaap de Wilde. 1998. Security: A new framework for analysis. Boulder, CO: Lynne Rienner.

Caballero-Anthony, Mely. 2008. Non-traditional security and infectious diseases in ASEAN: Going beyond the rhetoric of securitization to deeper institutionalisation. Pacific Review 12(4): 509-27.

Caballero-Anthony, Mely and Ralf Emmers. 2006. Understanding the dynamics of securitizing non-traditional security. In Non-traditional security in Asia: Dilemmas in securitization, ed. M. Caballero-Anthony, R. Emmers, and A. Acharya, 1-12. London: Ashgate.

Cornell, Svante E. 2005. The interaction of narcotics and conflict: A review essay. Journal of Peace Research 4(6): 751-60.

Dialogue and Research Monitor - Inventory of Multilateral Meetings on Asia Pacific Security and Community Building. 2003. Overview report. Online, http://www.jcie. or.jp/drm/2003/.

---. 2007. Overview report. Online, http://www.jcie.or.jp/drm/2007/.

---. 2008. Overview report. Online, http://www.jcie.or.jp/drm/2008/.

Dick, Howard. 2005. Southeast Asia as an open system: Geo-politics and economic Geography. In Locating Southeast Asia: Geographies of knowledge and politics of space, ed. P. Kratoska, R. Raben, and H. Schulte Nordholt, 250-74. Singapore: Singapore University Press.

Dupont, Alan, 1999. Transnational crime, drugs, and security in East Asia. Asian Survey 39(3): 433-55

---. 2001. East Asia imperilled: Transnational challenges to security. Cambridge: Cambridge University Press.

Elona, Jamie Marie. 2011. More women involved in drug trafficking. Inquirer, 3 Oct. Online, http://newsinfo.inquirer.net/69765/more-women-involve-in-drug-trafficking, accessed 15 Jun. 2013

Emmers, Ralf. 2003. ASEAN and the securitization of transnational crime in Southeast Asia. Pacific Review 16(3): 421-40. 
- - 2006. International Regime Building in Southeast Asia: ASEAN Cooperation against the Illicit Trafficking and Abuse of Drugs. Working Paper Series 106. Singapore: Institute of Defense and Strategic Studies.

Erviani, Ni Komang. 2011. Pregnant Philippine woman nabbed for drug smuggling. Jakarta Post, 19 Apr. Online, http://www.thejakartapost.com/news/2011/04/19/pregnantphilippine-woman-nabbed-drug-smuggling.html, accessed 15 Jun. 2013.

Fleetwood, Jennifer and Nayeli Urquiza Haas. 2011. Gendering the agenda: Women drug mules in resolution $52 / 1$ of the Commission of Narcotic Drugs at the United Nations. Drug and Alcohol Today 11(4): 194-203.

Gabriela Women's Party. Impending execution of OFW-drug mules. Online, http:// gabrielawomensparty.net/news/press-releases/impending-execution-ofw-drugmules-wake-call-end-labor-export-creation-local-job, accessed 12 Sep. 2012.

GMA News. 2006. Report: Mindanao terrorist groups resorting to drug trade. 17 Nov. Online, http://www.gmanetwork.com/news/story/21283/news/nation/reportmindanao-terrorist-groups-resorting-to-drug-trade, accessed 15 Jun. 2013.

--- 2011. DFA: Over 220 Pinoys in China's jails for drug trafficking. 19 Feb. Online, http:// wWW.gmanetwork.com/news/story/213413/pinoyabroad/dfa-over-220-pinoys-inchina-s-jails-for-drug-trafficking, accessed 15 Jun. 2013.

Haacke, Jürgen. 2009. The ASEAN Regional Forum: From dialogue to practical security cooperation? Cambridge Review of International Affairs 22(3): 427-49.

Haacke, Jürgen and Paul D. Williams. 2008. Regional arrangements, securitization, and transnational security challenges: The African Union and the Association of Southeast Asian Nations Compared. Security Studies 17: 775-809.

Hansen, Lene. 2006. Security as practice: Discourse analysis and the Bosnian War. Abingdon: Routledge.

Hasan, Nurdin. 2010. Militants in Aceh are Jemaah Islamiyah, say Indonesian police. Jakarta Globe, 17 Mar. Online, http://www.thejakartaglobe.com/archive/militants-inaceh-are-jemaah-islamiyah-say-indonesian-police/, accessed 15 Jun. 2013.

Herschinger, Eva. 2011. Constructing global enemies: Hegemony and identity in international discourses on terrorism and drug prohibition. Abingdon: Routledge.

Inquirer. 2011. De Lima orders NBI to crack down on drug syndicates. 18 Feb.

Jakarta Post. 2010. Drug body, NGO fight rise in lady couriers. 24 Jun. Online, http://www. thejakartapost.com/news/2010/06/24/drug-body-ngo-fight-rise-lady-couriers. html, accessed 15 Jun. 2013.

---. 2011. Editorial: Republic of drugs. 11 Mar. Online, http://www.thejakartapost.com/ news/2011/03/11/editorial-republic-drugs.html, accessed 15 Jun. 2013.

Jones, Lee. 2011. Beyond securitization: Explaining the scope of security policy in Southeast Asia. International Relations of the Asia Pacific 11: 403-32.

Kaplan, David and Alec Dubro. 2003: Yakuza: Japan's criminal underworld. Berkeley: University of California Press.

Kompas. 2010. 70 WNI Divonis Mati. 24 Aug. Online, http://health.kompas.com/ read/2010/08/24/03255531/70.WNI.Divonis.Mati, accessed 15 Jun. 2013.

Lee-Brago, Pia. 2011. Phl, Thailand to cooperate against drug trafficking. Philippine Star, 20 Apr. Online, http://www.philstar.com/headlines/677874/phl-thailand-cooperateagainst-drug-trafficking, accessed 15 Jun. 2013.

Lesaba, Marrah Erika. 2011. Recruiters of drug couriers watched. Inquirer, 19 Jun. Online, http://newsinfo.inquirer.net/16337/recruiters-of-drug-couriers-watched, accessed 15 Jun. 2013.

Lintner, Bertil. 2003. Blood brothers: The Criminal Underworld of Asia. Hampshire: Palgrave Macmillan.

Liow, Joseph Chinyong and Don Pathan. 2009. Confronting ghosts: Thailand's shapeless southern insurgency. New South Whales: Lowy Institute for International Policy.

Lyttleton, Chris. 2004. Relative Pleasures: Drugs, development and modern dependencies in Asia's Golden Triangle. Development and Change 35(5): 909-35.

Makarenko, Tamara. 2004. The crime-terror continuum: Tracing the interplay between transnational organised crime and terrorism. Global Crime 6(1): 129-45. 
McCoy, Alfred W. 2009. An anarchy of families: State and family in the Philippines. Madison: University of Wisconsin Press.

McDonald, Matt. 2008. Securitization and the construction of security. European Journal of International Relations 14(4): 563-87.

The Nation. 1993. Heroin has new hold amongst hill tribes. 19 May.

-- - 2007. Most of those killed in war on drug not involved in drug. 27 Nov.

New Straits Times. 2011a. 833 Malaysians held abroad for drug offences. 24 Apr.

- - 2011b. Drug mules driven by greed. 12 Nov. Online, http://www.nst.com.my/drugmules-driven-by-greed-1.4639, accessed 15 Jun. 2013.

---. 2011c. Drug mules now doped up on Facebook love. 26 Apr.

---. 2012a. African drug rings all over. 24 Feb. Online, http://www.nst.com.my/opinion/ columnist/african-drug-rings-all-over-1.51155, accessed 15 Jun. 2013.

- - - 2012b. More Malaysian women being used as drug mules. 11 Jan. Online, http://www. nst.com.my/latest/more-malaysian-women-being-used-as-drug-mules-1.30737, accessed 15 Jun. 2013

Observatory on Illicit Trafficking (Observatoire des Trafics Illicites). 2011. Information gathered during reasearch stay, Bangkok, Thailand.

OFW News Worldwide. 2010. Five Pinoy drug couriers arrested in Thailand. 5 May. Philippine Drug Enforcement Agency (PDEA). 2004. Annual report. Quezon City: PDEA.

---. 2005. Annual report. Quezon City: PDEA.

--_. 2006. Annual report. Quezon City: PDEA.

---. 2007. Annual report. Quezon City: PDEA.

---. 2008. Annual report. Quezon City: PDEA

---. 2010. Annual report. Quezon City: PDEA.

---. 2011. Annual report. Quezon City: PDEA.

Philippine Star. 2002. Mindanao groups eyed in Negros drug trade. 18 Jun. Online, http:// wWW.philstar.com/nation/165064/mindanao-groups-eyed-negros-drug-trade, accessed 15 Jun. 2013

-- . 2011a. DOJ, DILG urged to join task force on drug couriers. 1 Apr. Online, http:// www.philstar.com/breaking-news/671644/doj-dilg-urged-join-task-force-drugcouriers, accessed 15 Jun. 2013.

- - . 2011b. Drive vs int'l drug syndicates intensified. 7 Apr.

- - . 2011c. Gov't calls for holistic approach against illegal drug trade. 1 Apr. Online, http://www.philstar.com/breaking-news $/ 671676 /$ govt-calls-holistic-approachagainst-illegal-drug-trade, accessed 15 Jun. 2013.

-- . 2011d. Government gives priority to resolving drug menace. 31 Mar. Online, http:// www.philstar.com/breaking-news/671380/government-gives-priority-resolvingdrug-menace, accessed 15 Jun. 2013.

Praginanto, Gigin. 2009. Indonesia: The promised land. Jakarta Post, 11 Aug. Online, http://www.thejakartapost.com/news/2009/08/11/indonesia-the-promised-land. html, accessed 15 Jun. 2013.

Ramli, Fahirul N. 2012. "Drug mules knew what they're doing." New Straits Times, 9 Feb. Online, http://www.nst.com.my/top-news/drug-mules-knew-what-they-redoing-1.44090, accessed 15 Jun. 2013.

Ross, Michael. 2005. Resources and rebellion in Aceh, Indonesia. In Understanding civil war: Evidence and analysis, vol. 2, 35-58. Washington: World Bank.

Saragih, Bagus BT. 2011. RI, a "breeding ground" for terrorists, drug dealers. Jakarta Post, 31 Mar. Online, http://www.thejakartapost.com/news/2011/03/31/ri-\%E2\%80\%98abreeding-ground\%E2\%80\%99-terrorists-drug-dealers.html, accessed 15 Jun. 2013.

Sauler, Erika. 2012. "Recruiter" of Filipina drug mule executed in China re-arrested. Inquirer, 10 Sep. Online, http://globalnation.inquirer.net/49768/recruiter-of-filipinadrug-mule-executed-in-china-re-arrested, accessed 15 Jun. 2013. 
Segura, Cristian. 2010. Manila losing its battle with drugs. Asia Times Online, 24 Mar. Online, http://www.atimes.com/atimes/Southeast_Asia/LC24AeO1.html, accessed 15 Jun. 2013.

Shi-lan, Lee. 2012. Syndicates now target women from East Malaysia. New Straits Times, 31 Jul. Online, http://www.nst.com.my/life-times/sunday-life-times/syndicates-nowtarget-women-from-east-malaysia-1.117148, accessed 15 Jun. 2013.

Sidel, John. 1999. Capital, coercion, and crime: Bossism in the Philippines. Palo Alto: Stanford University Press.

Sun Star. 2011. Drug agency: 630 pinoy drug mules in jails worldwide. 17 Feb. Online, http://www.sunstar.com.ph/breaking-news/drug-agency-630-pinoy-drug-mulesjails-worldwide, accessed 15 Jun. 2013.

Tan, Andrew T. H. 2006. Southeast Asia: Threats in the security environment. Singapore: Marshall Cavendish Academic.

United Nations (UN) Commission on Narcotic Drugs, 2009. Promoting international cooperation in addressing the involvement of women and girls in drug trafficking, especially as couriers, UN Resolution 52/1. Online, http://www.unodc.org/ documents/commissions/CND-Res-2000-until-present/CND-2009-Session52/ CNDResolution_52_1.pdf.

2011. Promoting international cooperation in addressing the involvement of women and girls in drug trafficking, especially as couriers : Report of the executive director. UN doc.E/CN7/2011/7. Vienna: UN Economic and Social Council.

United Nations Office on Drugs and Crime (UNODC). 2009. Patterns and trends of amphetamine-type stimulants and other drugs in East and South-East Asia (and neighbouring regions). Global SMART Program.

-- . 2010. Patterns and trends of amphetamine-type stimulants and other drugs in East and South-East Asia (and neighbouring regions). Global SMART Program.

--- 2011a. Patterns and trends of amphetamine-type stimulants and other drugs in East and South-East Asia (and neighbouring regions). Global SMART Program.

-- - .2011b. World drug report. Vienna: UNODC.

2012. Patterns and trends of amphetamine-type stimulants and other drugs in East and South-East Asia (and neighbouring regions). Global SMART Program.

Vellema, Sietze, Saturnino M. Borras Jr., and Francisco Lara Jr. 2011. The agrarian roots of contemporary violent conflict in Mindanao, Southern Philippines. Journal of Agrarian Change 11(3): 298-320.

Williams, Michael C. 2003. Words, images, enemies: Securitization and international politics. International Study Quarterly 47: 511-31.

Yap, DJ. 2012. PDEA seeks licence to wiretap. Inquirer, 1 Mar. Online, http://newsinfo. inquirer.net/170389/pdea-seeks-license-to-wiretap, accessed 15 Jun. 2013.

STÉPHANIE MARTEL is doing her Ph.D. in Political Science at the University of Montreal, Canada. Her thesis focuses on non-traditional security cooperation in ASEAN. She has a Master's Degree from Université Lyon 2, France. Stéphanie is a coordinator at the East Asian Studies Center, University of Montreal, and she previously worked as an analyst at the Observatory on Illicit Trafficking in Bangkok, Thailand. <stephanie.martel.1@umontreal.ca> 